International Journal of Critical Indigenous Studies

Volume 9, Number 1, 2016

\title{
Rethinking Sociology, Social Darwinism and Aboriginal Peoples
}

\author{
Author \\ Associate Professor Kathleen Butler \\ Senior Teaching Fellow \\ Centre for Teaching and Learning \\ Academic Division \\ University of Newcastle
}

\section{About the Author}

Kathy Butler has recently taken up a position as Senior Teaching Fellow in the Centre for Teaching and Learning. A current OLT National Teaching Fellow, Kathy has a worked on numerous Teaching and Learning grants, including the Universities Australia funded Indigenous Cultural Competency Model Project as the Cultural Competency Coordinator. In 2014, she was the first Australian and first woman recipient of the Toihuarewa Visiting Indigenous Scholarship at Victoria University, Wellington, Aotearoa/New Zealand. Kathy is currently a member of the National Indigenous Research and Knowledges Network (NIRAKN).

\begin{abstract}
In various fora, Australian sociologists have recognised a need for greater Indigenous content and perspectives in their teaching practice. This paper addresses how this can occur through critiquing the inclusion of Darwin and Durkheim in undergraduate sociology teaching. It then provides a brief consideration of the author's own teaching practice and a workshop that she ran to address some of the problematic issues that she had identified.
\end{abstract}

\section{Keywords}

Sociology, intellectual traditions.

\section{Introduction}

Aboriginal and Torres Strait Islander inclusive education is a significant issue within the Australian higher education sector (Pechenkina \& Anderson 2011), which includes the Indigenisation of curricula. Attempts towards this goal are part of a rapidly expanding, if unevenly implemented, tertiary terrain. One approach has been the adoption of wholeof-university strategies for curricula reform. Alternatively, discipline-specific initiatives seeking a more targeted level of engagement have also been implemented. While acknowledging the importance of both of these approaches, this paper adopts a disciplinary focus, considering sociology as a discipline area with a self-identified need 
for innovation (Harley \& Natalier 2013). This paper discusses key sources that detail the nature of Australian sociology and potential transformations. The impact of Charles Darwin and Emile Durkheim are considered and this is linked to broader teaching practices, which have been implemented in the author's sociology courses offered through the University of Newcastle. These include an alternative to the 'guest lecture' and the inclusion of Aboriginal and non-Aboriginal stories.

\section{The Context of Australian Sociology}

Participants at numerous Australian sociology forums have expressed a desire for greater inclusion of Indigenous knowledges. There is also an understanding that this will necessitate restructure, yet there is limited academic literature in Australian sociology about tertiary teaching and Indigenisation. This is best evidenced by the Journal of Sociology creating special issues for both of these topics to try to stimulate discussion.

This section draws heavily on two significant sources: The Journal of Sociology_Indigenous Issues (2006) and Teaching Sociology (2013), as well as Teaching Sociology in Australia: A Report to the Australian Learning and Teaching Council (Marshall et al. 2009). Overall, the potential for sociological reform is summed up, "I think that it would be an enormously exciting project to restructure sociology teaching around other forms of knowledge, including Indigenous knowledge within Australia" (Marshall et al. 2009, 40).

Sociology is broadly adopted within Australian higher education as 35 of the 37 public universities have undergraduate sociology offerings. Despite this, there is no national network concerned with teaching, although this is frequently mentioned as being beneficial (Marshall et al. 2009, 12, 16; Harley \& Natalier 2013, 390). Sociology teaching occurs both within sociology departments and in numerous other departments, which fragments the potential for collegial conversations (Marshall et al. 2009, 30; Walter, Pyett, Tyler \& Vanderwyk 2006). For Indigenous scholars, this is even more marked, as demonstrated by the editorial in the Indigenous special issue of the Journal of Sociology, where it is noted that none of the papers published were authored by academics identifying predominantly as sociologists at the time (Walter, Pyett, Tyler \& Vanderwyk 2006, 342). Further, service teaching of sociology into other degree programmes represents unique challenges for teaching sociology, both in terms of content and staffing (Marshall et al. 2009, 27, 34-38; Harley \& Natalier 2013, 390).

In a national mapping process, 93 members of The Australian Sociological Association (TASA) were listed as interested in 'Aborigines \& Indigenous People'. However, there is a complete disjuncture between this interest and teaching practices with only five corresponding subjects offered nationally in sociology (Marshall et al. 2009, 18). There is clearly space for this to be expanded. In 2012, the University of Sydney hosted a 'Theorising Indigenous Sociology' seminar that bought together Indigenous and non-Indigenous scholars to stimulate the development of this area. As a result of this seminar, McAllen $(2012,3)$ questioned, 
Does this mean we cannot have conversations in which such sociological terms (and related theories) are employed as critical tools? I would say that they can still be useful, as long as the terms are qualified in specific relation to indigenous [sic] experience/ontological perspective - thus also taking care that the terms are socio-politically and historically located.

I would extrapolate on McAllen's perspective, that, to Indigenise sociology in a meaningful way, the discipline's fundamental works and terms need to be interrogated.

\section{From Darwin to Durkheim}

Examining standard first year tertiary sociology textbooks, there is often a narrative that relies on a standard linear timeline, with little mention of Aboriginal cultures pre-contact and most post-contact analysis focussing on imposed policy periods and current statistical deficits for Aboriginal people in all social indicators. Markedly absent are interrogations of the discipline itself, Aboriginal voices and epistemologies, and a general theoretical vacuum beyond a section about social Darwinism. Plummer $(2012,45)$ provides a typical summary:

And just as Darwin was busy studying and comparing different kinds of plants and animals across the world, so many of the earliest sociologists, historians and anthropologists were busy drawing out comparisons between different kinds of societies in the past and present... Often they were exploring countries that Europe had invaded, colonised and Christianised. And with full blown ethnocentrism they often saw these cultures as inferior to their own.

While I would acknowledge a significant shift, where what was previously termed 'European expansion and discovery' is now referred to as 'invasion', there is still an erasure of Darwin's own part in developing social Darwinism. Anthropologist Bernard Smith $(1980,20)$ argued that Darwin "cannot be exonerated entirely from the charge of vulgarising his own theory" as, in his global travels, Darwin deliberately sought to 'view' Indigenous peoples as part of his own deliberations on the application of his principles to humanity. I consider it an intellectual 'white-washing' to term this 'ethnocentric', preferring instead to label it as racist. Yet, because of the normalisation of the discourse positioning Darwin in the natural sciences, very few sociologists have questioned his role. In Australia, only Raewyn Connell has done so and the nature of her analysis says much of the difference between a non-Aboriginal and Aboriginal lens being applied to intellectual traditions, although it should be commended for its initiation of the discussion and call for ongoing dialogue.

Darwin's relationship to Australia is considered in Raewyn Connell's (2007) discussion of the global south and Southern theory: the global dynamics of knowledge in social science. As one of Australia's highest profile sociologists, 
Connell led some of the most significant debates in Australian sociology during the twentieth century, particularly in the areas of gender and class. In the twenty-first century, Connell turned her attention to the centrality of the European 'metropole' in sociological theory, arguing for the recognition of the contribution of the global south and its southern theory. In considering the Australian situation, Connell discusses European intellectual reflections on Australia, including those of Charles Darwin, quoting Darwin's description of Aboriginal ceremonial dancers "all moving in hideous harmony, formed a perfect display of a festival amongst the lowest barbarians" (Connell 2007). Her analysis of this is that,

Despite the pejoratives, Darwin was not hostile [emphasis added] to the Australian Aboriginal groups he met. He admired their bushcraft and hunting skills, sympathised with their vulnerability to imported diseases, and did not blame them for the frontier violence. But he did regard the Australian Aborigines as a more primitive people than the British; he expected their extinction, and he saw this as an unavoidable consequence of a stronger variety of man meeting a weaker: 'Wherever the European has trod, death seems to pursue the aboriginal'. (Darwin 1839: 411)

While I am mindful of the differing language conventions of the time, I still cannot agree with Connell's assertion that Darwin was not 'hostile' to Aboriginal people. Darwin's works are rife with epistemic violence (Spivak 1998) towards Aboriginal people and to other Indigenous people globally when terms such as 'savage', 'hideous', 'primitive', 'hostile', 'miserable', 'filthy' and 'wretched' predominate his writing (Armstrong 2010, 137-138).

Perceived Indigenous irrationality was such that Darwin, in comparing it to the self-reflection of his dog, questioned "how little can the hard-worked wife of a degraded Australian savage, who uses very few abstract words, and cannot count above four, exert her self-consciousness, or reflect on the nature of her very existence" (Smith 1980, 20).

In linking his theory to the decline of Indigenous peoples and classifying Indigenous peoples according to their 'Stone Age' implements, juxtaposed to the technological superiority of the invaders, Darwin contributed to the inference of moral neutrality in judging frontier violence (Smith 1980, 20). In doing so, biological 'fact' became linked to social reality. Thus, while science concerned itself with evolution viewed through a Darwinist lens, early sociology adopted social Darwinism as an explanatory mechanism for understanding the 'demise' of Aboriginal people and as a justification for classifying Aboriginal cultures as the most primitive in the world.

Initially for sociologists, Indigenous people and cultures figured as a 'data mine for material on the primitive (sic)' (Connell 2008; Marshall et al. 2009, 78) used by white, male intellectuals in Europe and returned to the Australian context interpreted through that Eurocentric lens. One of the key intellectuals in this process was Emile Durkheim, who is widely considered to be one of the founding fathers of sociology. Even my own undergraduate major in 
sociology in the 1990s included a compulsory component about the 'History of Sociology' that used sections of Durkheim's work, The Elementary Forms of Religious Life (1986), which suggests that Aboriginal people practiced the most 'primitive' belief systems. Despite the fact that Durkheim was roundly criticised by other intellectuals at the time, and this has continued, the work has remained a sociological classic to a global audience. A scant 30 years ago, an American reprint was introduced by Robert Alun Jones $(1986,115)$,

But if Durkheim's goal was thus to understand modern man, why did he go to the very beginning of history? How can the crude cults of the Australian aborigines [sic]tell us anything about religions far more advanced in value, dignity, and truth? And if he insisted that they can, wasn't he suggesting that Christianity, for example, proceeds from the same primitive mentality as the Australian cults?

While it would seem that this is the type of work that begs for a rebuttal from contemporary Australian sociology, the opposite has been true. Once again, it is Connell who has attempted to initiate debate. While Connell provides a quote critiquing Durkheim, Connell's $(2005,63)$ own analysis is far softer,

'Australian totemism' fitted the bill, because Australian Aborigines had the most primitive documented society. Here the crude racism of a Ward or Sumner is transcended-up to a point. Durkheim's prejudice takes a very sophisticated form; his sociology embeds a deeply ethnocentric viewpoint nonetheless.

The language used-'prejudice' and 'ethnocentric'-ameliorates the offensiveness of the Durkheim's position. In the Journal of Sociology, I responded to Connell's analysis of Durkheim as follows:

While, for Connell (2005), the sophistication of Durkheim's writing allows it to 'transcend the crude racism of others', as a member of the colonized I cannot see the ameliorating effects of 'scholarship' on racist conclusions. In fact, I deplore it all the more because it emerges from the academy and as such retains a legitimacy now denied to the 'common' public expression of racism. (ButlerMcllwraith 2006, 375-6)

It was as a consequence of engaging in this debate that I felt moved to critically re-examine my teaching of sociology and interrogate my own takenfor-granted acceptance of the discursive norms in the discipline. I began to extend the development of my own pedagogy, bringing my own identity as an explicit lens in my teaching. As Rothman $(2005,10)$ states,

More and more sociologists are doing just that: mining our own lives, our own experiences. Just as the anthropologists have moved closer to home, losing some of their fascination with exotica and exploring their own locales, sociologists have moved in closer as well. But for us, it was never about sailing off to some island somewhere -we were always exploring close to home. Increasingly, 
though, we've come closer and closer, turning our sociological eyes on our own lives.

This was a dynamic field for me because it was engaged, not as a discreet "trip", but as an everyday practice of "teaching the field" (Corsin-Jimenez, cited in Fechter 2003, 1). In this, it is a form of "action teaching" (Plous 2012) and remains consistent with an Aboriginal worldview because, as Hughes $(2000,1)$ notes, the "indigenous [sic]community action cycle of aims, actions, observations and stories corresponds to the action research cycle of plan, act, observe and reflect". As an everyday practice, which can be reflected upon, teaching through a sociological lens can be, in itself, an ongoing, lived pedagogy. In the remaining discussion, I will provide the example of the 'Indigenous Intellectual Traditions in Action' workshop at the Central Coast campus that I conceived and implemented as a means of addressing the concerns listed above and the process of valuing Aboriginal and nonAboriginal stories that it entailed.

\section{Indigenous Intellectual Traditions in Action}

The Central Coast campus was the second campus established by the University of Newcastle approximately 80 kilometres from the main campus in Newcastle, at Ourimbah. Offering a smaller suite of programmes and courses, students from Ourimbah sometimes lament missing the vibrant extracurricular student activities of the main campus. Additionally, the student base has many mature-aged mothers who are unable to participate in after-hours campus life. In formulating the day workshop, my aim was to provide a curriculum that met two goals:

1. The curricular justice goal, which has as its objective the provision of educational opportunity and outcomes.

2. The wider responsibility goal, which focuses on educating all students for social justice and anti-racism through programmes of anti-racism education (Vigilante, cited in Butler \& Young 2009, 51).

In terms of content, I returned to two of the key issues addressed by the founding fathers of sociology-the structure and use of religion; and capitalism and its effect on communities. Rather than positioning these works in their original context, I decided to source Aboriginal community members whose presentations would address the synergies between Aboriginal and European knowledge systems, positing that the Indigenous knowledges should also be recognised as 'intellectual traditions'. To give impetus to the ongoing relevance of Aboriginal knowledges, I added the phrase 'in action'. It also recognised the concept of "action teaching", which refers to "a style of instruction that contributes to peace, social justice, and sustainable living at the same time as it educates students" (Plous 2012, 1). Thus the workshop, 'Indigenous Intellectual Traditions in Action' was born!

As part of my deliberations, I wanted to move away from the one hour guest lecture where Aboriginal community members are separated from the 
students, in a traditional speaker/audience format, with little opportunity for meaningful interaction. Moreover, the guest lecturer will generally not be present for the later tutorial discussion and, as such, there is tendency for the autobiographical lecture to be reduced to a 'case study' that is then reinterpreted and digested through the standard disciplinary lens. As such, the hegemonic power of the discipline is reinforced, rather than challenged. I also wanted to avoid what Professor Bob Morgan refers to as the "guest paradigm" where Aboriginal people are "treated as guests in the dominant educational domain" (Morgan, cited in Wakatama 2016). The workshop was constructed with plenty of breaks when the presenters would be able to mingle with the students in an informal setting. Understandably, this was a more costly approach, but the Deputy-Vice Chancellor Academic, Professor Kevin McConkey, provided 'Equity Initiative Funding', which supported speakers, travel and food. Logistically, the Aboriginal Project Officer, Annie Vanderwyk, at the Gibalee Centre on campus did the majority of organisation, as well as supporting and sourcing the speakers.

The workshop activities focussed heavily on 'story'. I believe that the inclusion of 'story' is a legitimate, academic discourse, that 'stories' can be rigorous and deserve to have the recognition as such (Nichols, 2004). While this is an important growing field of resources, some academics scoff at their inclusion, often challenging it as being inappropriate within the academy-"unscientific or atheoretical ... subjective and ... of no professional relevance" (Carr 2004, 8). Others temper this slightly, but still provide a clear delineation of where these usages 'belong'. Indeed, Patton (cited in Ricci 2003, 594) experienced this when told "those who want to write creative non-fiction or poetry should find their way to the English Department of the university and leave sociology to the sociologists".

Native American scholar, Thomas King $(2003,2)$, claims "the truth about stories is that's all we are". I agree. The workshop showed that 'stories' can evidence the intersections of teaching sociology and the Aboriginal experience in a way that synthesises the narrative traditions of Indigenous and academic origins, demonstrating that these need not be competing. Beyond that desire is a deeper consideration of the processes of critical thinking, when we can move beyond just giving testimony to analysing and reconfiguring our understanding of events within an intellectual framework engaging in both a telling and retelling of stories that shape the academy and our communities. What we need to do is "to write our stories in our own voices and to create our own images of ourselves. When we do not, others write our stories for us, and we are in danger of accepting the images others have painted of us" (Chiu 2004, 43).

The first speaker of the day was Aunty Joan Hendriks who presented on Interfaith Dialogue, drawing on her work with Associate Professor Gerard Hall $\mathrm{SM}$ at the Australian Catholic University. Using the principles of 'Rainbow Spirit Theology', Aunty Joan showed students a context in which 'Aboriginal Dreaming' had been applied to Christianity, particularly Catholicism. Using a multimedia presentation, Aunty Joan provided artworks that were visual representations of her stories. 
The second speaker, Rod Williams, spoke about the issue of 'Economic and Cultural Negotiations', founded in the 'Gongan framework', and based on the story of his consultancy work between government community and industry. Rod Williams describes this as:

When watching business talks between business, government and Aboriginal community representatives, I observed that:

- Business - spoke of profits and industry standards;

- Government - spoke of programs and measurable outcomes;

- Aboriginal community - spoke of a holistic approach taking [in] culture, social justice, environmental protection and business development.

The three groups often present their directions in a language that usually leads to misunderstanding and misinterpretation. The Gongan framework models were developed to give the parties a common language and framework to work through at the consultation and negotiation stages. (Williams nd).

In order to respect Rod Williams' cultural and intellectual property of this framework, I will not describe it in any further detail, other than to say that it provided a means for profitable interactions, while not undermining cultural integrity and sustainability.

Several activities also occurred in the courtyard of the humanities building with bush tucker provided by Deborah Swan, the Cultural Officer from the local land council. Debbie also explained the spiritual links between the sustainable use of environmental resources for healthy 'country', healthy communities and shared economic prosperity. The courtyard was also used for a reading of poetry from Bobby Macleod (2008). Students had the opportunity to discuss the workshop with speakers and to ask further questions according to their interests. Most pleasingly, students also had the opportunity to share their stories with the presenters as well.

I caution, here, that students also need to be given the option not to share a story, but to understand that being part of the audience for others is in itself a participatory feature, rather than passive. Moreover, it needs to be understood that some stories are 'unspeakable' because of the pain and trauma with which they are associated (Gregoriou 2005). Once this is accepted, there is a strong foundation for students to then engage cross-culturally. They are more prepared to consider Aboriginal perspectives from their own position.

Student feedback about teaching from the workshop was very pleasing:

I really enjoyed the workshop, it was a real privilege to be there. 
I had a brilliant day Friday, I was left with so much to think about. Thank you for all your hard work that you put in into organising the events and big thanks to all speakers.

Her content knowledge is amazing, not just how it relates to aboriginal studies [sic] but to the wider context of the social sciences and its relevance in social enquiry.

Since then, I have also had non-Aboriginal colleagues use the methods of story-telling in their sociological classrooms. Feedback from one was as follows:

It went really well - some lovely stuff came out of it. They are engaging with the material both intellectually and emotionally, and engaging with each other very collaboratively ... I still haven't reported back properly on last week - asking them to share their stories ... It was such a lovely session - a real privilege to share it with the students. They were on such a high after it - a couple of them said after it was the best thing they'd ever done at uni! I am to send on their thanks to you for the idea!

\section{Conclusion}

There is clear scope for Australian sociology to expand its engagement with Indigenous issues and knowledges. Before this can happen, however, there needs to be a reconsideration and, if possible, reconciliation with past beliefs and practices. Social Darwinism cannot merely be figured as being part of a linear progression in the historical development of racism, but as a pervasive, intellectual cancer that continues to impact upon Aboriginal peoples. Similarly, we need to stop reifying sociological figures such as Durkheim and actively speak against their use of Aboriginal people as 'data'. Aboriginal sociologists have much to offer the discipline, in both critique and pedagogical alternatives. I look forward to seeing dialogue, followed by action, in this area.

\section{References}

Armstrong, Patrick. 2010. "Charles Darwin's observations on humanity during the Beagle voyage." Accessed 31 July 2015. http://museum.wa.gov.au/sites/default/files/14.\%20Armstrong.pdf

Butler-Mcllwraith, Kathleen. 2006. "Representing Indigeneity: The possibilities of Australian Sociology." Journal of Sociology 42 (4).

Butler-Mcllwraith, Kathleen. 2008. "Social Justice, Indigenous Australians and Catholicism." Australian Ejournal of Theology 11.

Carr, David. 2004. "Professional and Personal Values and Virtues in Education and Teaching." Philosophy of Education Society of Great Britain Conference Programme and Papers. Accessed 2 March 2010. http://www.ioe.ac.uk/pesgb/z/Carr.pdf 
Chiu, Jeannie. 2004. "'I salute the spirit of my communities': Autoethnographic Innovations in Hmong American Literature." College Literature 31 (3).

Connell, Raewyn. 2007. Southern theory: the global dynamics of knowledge in social science. Cambridge: Polity Press.

Connell, Raewyn. 2005. "Australia and World Sociology." In Histories of Australian Sociology, edited by John Germoy and Tara McGee. Melbourne: Melbourne University Press.

Craven, Rhonda. 1998. "Getting Started: Understanding and Teaching Aboriginal Studies Effectively." In Perspectives on Aboriginal and Torres Strait Islander Education, edited by G Partington. Katoomba: Social Science Press.

Creed, Barbara. 1994. "Queer Theory and Its Discontents: Queer Desires, Queer Cinema." In Australian Women: Contemporary Feminist Thought, edited by N Grieve and A Burns. Melbourne: Oxford University Press.

Fetcher, Anne-Mieke. 2003. "Cultures in the Classroom: Teaching Anthropology as a 'Foreigner' in the UK." Anthropology Matter Journal 2003.

Gongan Consultancy. Accessed 15 July 2015. http://www.gongan.com.au/

Gregoriou, Zelia. 2005. "Before the Educational Violence of commemoration: Derrida and the philosophical work of mourning." Paper presented at the 2005 Philosophy of Education Society and Great Britain. Accessed 3 April 2012. http://www.ioe.ac.uk/pesgb/x/Gregoriou.pdf

Harley, Kirsten, and Kristen Natalier. 2013. "Teaching Sociology- reflections on the discipline." Journal of Sociology 49 (4).

Hughes, Ian. 2000. "Ganma: Indigenous Knowledge for Reconciliation and Community Action." Action Research Report. Accessed 14 May 2012. http://www2.fhs.usyd.edu.au/arow/arer/pdf\%20eReport\%20version/014.pdf

Jones, Robert. 1986. Emile Durkheim: An Introduction to Four Major Works. Beverly Hills, CA: Sage Publications.

King, Thomas. 2003. The Truth About Stories: A Native Narrative. Minneapolis: University of Minnesota Press.

McLaren, P, and Z Leonardo. 1998. "Deconstructing Surveillance Pedagogy: Dead Poets Society." Studies in Literary Imagination Spring.

McLeod, Bobby. 2008. Ngudjung Yugarang: "Mother's Heartbeat". Nowra: BMAC Publishing.

Marshall, Helen, Peter Robinson, John Germov and Eileen Clark. 2009.

"Teaching Sociology in Australia: A Report to the Australian Learning and Teaching Council." Accessed 26 July

2011. http://apo.org.au/files/Resource/ds7623 teaching sociology in a ustralia final report.pdf 
McAllen, Fiona. 2012. "Notes on Theorising Indigenous Sociology seminar." NEXUS Newsletter of The Australian Sociological Association. Accessed 10 February 2016. https://www.academia.edu/2101323/Theorising Indigenous Socio logy

Pechenkina, Ekaterina, and Ian Anderson. 2011. Background paper on Indigenous Australian Higher Education: Trends, Initiatives and Policy Implications. Canberra: Department of Education Employment and Workplace Relations.

Plous, Scott. 2012. "Action Teaching." Accessed 14 March 2015. http://www.socialpsychology.org/pdf/encyclopediapeace.pdf?logged=true

Ricci, Ronald. 2003. "Autoethnographic verse: Nicky's Boy: A Life in Two Worlds." The Qualitative Report 8 (4).

Smith, Bernard. 1980. The Spectre of Truganini. Sydney: Australian Broadcasting Commission.

Spivak, Gayatri. 1988. "Can the subaltern speak?" In Marxism and the Interpretation of Culture, edited by Cary Nelson and Lawrence Grossberg. Urbana: University of Illinois Press.

Walter, Maggie, Priscilla Pyett, Bill Tyler and Annie Vanderwyk. 2006. "Beyond margins/Beyond Marginality." Journal of Sociology 42 (4).

Tsey, Komla, and Ernest Hunter. 2002. "Indigenous health and the contribution of sociology: a review." Health Sociology Review 11 (1).

Wakatama, Giselle. 2016. "Newcastle academic slams 'Eurocentric' education for Indigenous students." ABC Newcastle. Accessed 5 February 2016. http://www.abc.net.au/news/2016-01-19/newcastle-academicslams-eurocentric-education-for-indigenous/7097160 